\title{
Life in Palestine Under the Rule of the Ottoman Empire According to Ibrahim Nassralla's Novel: Zaman al-Khoyoul al-Bayda ${ }^{\prime}$
}

\author{
Rawiya Burbara, Ph.D.
}

Doi: 10.19044/llc.v8no4a1 $\quad$ URL:http://dx.doi.org/10.19044/llc.v8no4a1

Submitted:17 August 2021

Accepted: 16 December 2021

Published: 31 December 2021

\author{
Copyright 2021 Author(s) \\ Under Creative Commons BY-NC-ND \\ 4.0 OPEN ACCESS
}

\begin{abstract}
This study deals with the Palestinian administrative, economic, political, educational, intellectual, and national dimensions as they are reflected in the stories and events of the historical novel Zaman al-Khoyoul al-Baida' by the Palestinian writer Ibrahim Nassralla, The novel that covers three generations from 1880s to the establishment of the State of Israel in 1948. The events take place in a Palestinian village called 'Hadiya ${ }^{2}$, , which serves as a representative of all Palestine. The study proves that the writer emphasizes the Palestinian
\end{abstract}

${ }^{1}$ Nassralla, Ibrahim (2007). Zaman al-Khoyoul al-Bayda'. Beirut. Al-Dar al-'Arabiya li al-U'lum Nashirun. The novel was shortlisted for the 2009 International Prize for Arabic Fiction. In 2012, it was translated into English by the American translator Nancy Roberts and published by the American University in Cairo Press. For reviews and comments on the novel in English, see: Marcia Lynx Qualey (January 24, 2012) Arablit. Blog; Tam Hussein (December $4^{\text {th }}, 2012$ ) Review of Time of the White Horses in: the New Statesman - Online; Norbert Hirschhorn (2012). Time of White Horses, in: Banipal: Magazine of Modern Arabic Literature-Online; Benjamin Hollander (January 24, 2013). A Palestinian Odyssey: Warscapes-Online; Raya-Agency for Arabic Literature (January 27, 2013). A Review of Nassralla's Time of White Horses-Online.

${ }^{2}$ Saleh, Fakhri (2020). "Al-Nakba wa al-Riwaya". At al-Arab Website: https://alarab.co.uk. retrieved on 09/02/2020. Saleh points out that Nassralla chose the novel Zaman al-Khoyoul al-Bayda'/Time of White Horses to start narration in the last quarter of the nineteenth century, when the Ottoman Occupation settled in Palestine and the Arab Mashreq in general The people of al-Hadiya village, which parallels with Palestine, suffered from the Ottoman soldiers and their injustice and suppression. then the novel moves to the British Mandate period till it reaches the point of fall of Palestine

, where the citizens of al-Hadiya defended their village despite the treason of the Arab rulers and the failure of the traditional Palestinian leaders and the help of the British to the Jews to take over Palestine after the end of the Mandate. 
identity through the stories that he collected from people who lived through the three periods of occupation of Palestine: the Ottoman Empire, the British Mandate and Israel, but the main focus is on the Ottoman Period. Stylistically, the novel has a special printing style. The oral stories are typed in italics in order to distinguish them from written stories. To investigate the information in the people's quoted stories, the events of the novel and the writer's arguments and his descriptions of the life of local Palestinians, the study relies on Paul Hamilton's theory of historicism ${ }^{3}$, which is a critical way of using historical contexts to interpret narrative texts.

Key Words: Ottoman rule, Palestine, administrative, economic, educational, intellectual, national, historicism.

\section{Introduction}

Palestine had been under the Memluke rule before it came under the Ottoman rule in 1516 after the victory of Sultan Selim I in the Battle of Marj Dabiq. Sultan Selim arrived in Palestine without war at all and entered Jerusalem after he had prayed two rak'ahs (kneels in prayer) thanking God outside its walls. The scholars ('ulama') of Jerusalem, its dignitaries and all its people went out to welcome Sultan Selim and congratulate him and hand him the keys of the city. This scene reminds us of the scene of the entrance of Caliph Omar Ibn al-Khattab to Jerusalem in 637 AD. However, the people of Jerusalem at that time refused to hand the keys of the city to anyone else. When Omar entered the city, he prayed two rak'ahs (kneels) at the site of Omar Mosque today. The difference between the entrance of Omar Ibn alKhattab and Selim I is that Omar entered it against the consent of its people but he intended to prevent any bloodshed in order to encourage the people to convert to Islam. Sultan Selim I, however, entered the city with the people's consent and they welcomed him and showed their love. On his way to Jerusalem, Sultan Selim did not face any resistance or opposition and he was welcomed with pleasure and joy.

Palestine became a part of the Ottoman Empire 217 years after its establishment. The affairs of the Empire by that time had started to settle down from the administrative point of view. During the period of Sultan Selim I, and his son Suleiman the Magnificent, the Law-Giver, Palestine received special care and the Empire at that time was at the peak of its prosperity. Mosques were established and schools were opened and the number of schools in Jerusalem only reached 69, Besides, there were 40 Zawaya (Corners) in Jerusalem besides the main school in the al-Aqssa Dome. The Takkiyat (hospices/ poorhouses) were also established and the existing Wall was built around Jerusalem.

${ }^{3}$ For application of this theory in research, see: Sudiro Suryo, M. Hum (2020). The Depiction of Native American in the Novels of Forrest Carter, International Journal of Linguistics, Literature and Culture, March, vol. 7, N0. 1., p. 15; for full description of the theory, see: Hamilton, Paul (1996). Historicism. New York: Routledge. 


\section{The Novel : Zaman al-Khoyoul al-Baida'/ Time of White Horses}

Zaman al-Khoyoul al-Baida' is a part of a series of novels called alMalha al-Falastiniyal The Palestinian Comedy, which the world is used to refer to as "The Palestinian Tragedy", which the writer considers as a 'comedy' because he wants the reader to see the other side that is generally unseen by others as it is not documented, neither socially nor historically.

Zaman al-Khoyoul al-Baida' describes the situation that prevailed in Palestine before the Nakba (Catastrophe) in 1948). The historical and social description is intended to give a clear image about the real life that prevailed in the region and all the conditions and circumstances that led to the tragedy.

"Time of White Horses spans three generations, from the end of the nineteenth century to the end of the British Mandate. Empires fall, rulers change, and bitter struggles take place between the Turks, the British, Jewish immigrants, and Palestinian leaders, city dwellers and villagers. The stories in the novel are orally transmitted from generation to generation. The writer collected them over twenty years, and they are typed in italics in order draw the attention of the reader to their authenticity.

Salma Khadhra'a al-Jayyusi says about the novel to the Iliad, says:

"It is duly the novel that the Palestinian Nakba was waiting for and did not get it before. It is an accurate history, of high sensitivity and creative description, of the Palestinian situation since the Ottoman Empire to 1948. It is of great importance because it clearly reveals the causes of the Nakba and its circumstances".

Abdullah al-Buraymi says:

"In Zaman al-Khoyoul al-Baydha', Ibrahim Nassrallah sought to introduce a new memory that is derived from the collective memory; it includes it but is not similar to it, or largely differs from it, and he, with this achievement, wanted to surprise those who know Palestine, that they did not know Palestine well. This novel went far into the history of the Palestinian people to the end of the nineteenth century till the middle of the twentieth century; 129 years of the history of the Palestinian people, which Ibrahim Nassaralla wove within three oral narratives: The spoken narrative of the wind, the spoken narrative of the earth, and the spoken narrative of the people.. ${ }^{5}$

The main aim of the Study is to find out how the administrative,

political economic, political, and educational conditions in Palestine

\footnotetext{
${ }^{4}$ Al-Jayyusi, Salma al-Khadra (2009). Tiba'ah Khassah min al-Malha al-Falastiniya li Ibrahim Nassralla. In Jaridat al-Ghad: A Reserved Copy on May, $26^{\text {th }}, 2009$. 5 5 al-Buraymi, Abdalla (2006). Ibrahim Nassrallah... al-Adab Tanqiya li al-Dhakera wa Ansana li al-Tarikh, in: Mawsu'at Anhath wa Dirasat fi al-Adab al-Falastini alHadith. Part 4, p. 12.
} 
under the rule of the Ottoman Empire are reflected in the novel Zaman al-Khoyoul al-Baida'l Time of White Horses and if those conditions contributed to the early formation of the Palestinian national identity that has reached its peak in the twentieth century.

\section{Questions of the Study}

To achieve its goal, the study poses the following questions:

- To what extent do the stories represent the life of the local people of Palestine in that period?

- To what extent do the stories that the writer collected from people who lived through the three periods of occupation of Palestine - the Ottoman, the British and the Israeli contribute to the emergence of the Palestinian identity and nationality.

\section{Methodology}

The study adopts the method of socio-political and historical discussion of the text, the events, and the oral stories that constitute the main material of the novel. The main theory that this study relies on is the theory of "Historicism", which helps the researcher to interpret accurately the implications of the oral texts. Surio Sudiro (2020:15) quotes Paul Hamilton (2003:2) definition of "Historicism" as: "Historicism (or 'historism' in this translation of Currius' Historismus) is a critical movement insisting on the prime importance of historical context to the interpretation of texts of all kinds."

This study also depends on Historicism as an analytical instrument that brings together literary interpretation and historical explanation. It means drawing upon the events recorded in academic history books and comparing it to the story in the novels. However, this study relies more on "people's stories" and considers them reliable because they come from people who lived the actual experiences and kept them by heart.

Before answering the above question, the study discusses the main sociopolitical dimensions that the researcher believes contributed to the evolution and development of the Palestinian identity that has its own features characteristics. Besides, it tries to find how the political fluctuations in Palestine, and the fall of the Ottoman Empire, and the British Mandate on Palestine, enhanced the emergence of the Palestinian identity. The study focuses on the five main dimensions that affected that emergence:

\section{Discussion}

This section discusses the administrative, demographic, political, economic, educational, intellectual and national dimensions in Palestine between 1880-1948. The discussion relies on both written official historical 
documents and oral popular stories that the researcher collected from the local people who lived in Palestine in that period.

\section{The Administrative and Demographic Divisions}

Palestine was divided into administrative regions and each one was called (Snajaq/Sanajek), whose areas changed throughout the period of the Ottoman rule. At the end of the Ottoman era, Jerusalem became an independent province (Muatasarrifate) of Syria and became connected directly to Istanbul in 1873 (or 1874). It included the following districts (aqdhiya): Al-Quds (Jerusalem), Jaffa, Gaza and al-Khalil (Hebron). At the end of 1899, a new district was established in the southern province Beer alSabi' (Beersheva). The Jerusalem Province preserved its administrative borders till the end of the Ottoman rule, "except for the period between June 1906 to July-1909, when the Province of Nazareth was joined to it after it had been disconnected from the Province of Akka (Acre), which belonged to Beirut Vilayet (Province) in response of the Ottoman Empire to the request of the European countries to make the visits of the pilgrims to the holy places that exists in the province more convenient ${ }^{6}$.

The Ottoman rulers divided Bilad al-Sham (Syria) into three provinces (Vilayets): Aleppo, Tarablus (Tripoli) and al-Sham, which was divided into several Snajaks (alwiya/districts): Damascus, Tadmor, Ajloun, Karak, Gaza, al-Quds, Nablus, Safad and al-Lajjun ${ }^{7}$.

The Liwa' (district) comprises several Nawahi (sub-districts) and each Nahiye (sub-district) included a number of villages. The purpose of this division was statistical and financial as each financial unit consisted of a city, a village, a farm or a tribe in a certain area; each one brought revenues to the Ottoman State according to the size of its population and its land and consequently, its income. The incomes were divided into three parts: One part goes to the Sultan (Padishah) ; another part goes to Amir al-Liwa' (Sanjak-bey) and in both cases the part constitutes Iqta' (feudal) of a "private" kind; a third part goes to the Timar (grant of lands or revenues by the sultan to an individual in compensation for his services) and Za'amet, (a form of land tenure in Ottoman Empire, consisting in grant of lands or revenues by the Ottoman Sultan to an individual in compensation for his services, especially military services) who were their cavalrymen (Sipahis) and their officers who were given Iqta' (feudal estates) instead of their wages ${ }^{8}$.

At the beginning of the Novel of Zaman al-Khoyoul al-Baida/ Time of White Horses, we read about the Honorable new Qaimaqam/ Kaymakam

\footnotetext{
${ }^{6}$ Rafiq, Abd al-Karim (1990). Falastin fi 'Ahd al-Uthmaniyyin. 2, p. 851-874; Awad, Muqaddima fi Tarikh Falastin al-Hadith, p. 20-21.

${ }_{8}^{7}$ Al-Bakhit (1979) Haifa fi al-'Ahd al-'Uthmani al-Awal, p. 301.

${ }^{8}$ Rafeq, Abd al-Karim (1990), Falastin fi 'Ahd al-Uthmaniyyin, 1, p. 810.
} 
(Lieutenant) who was making a round to see the conditions of the new area that became under his authority. That Qaimaqam met a fearless brave Palestinian Arab in whose flank he planted his sword but the man did not cry "Ugh!". The Qaimaqam left him in the Inn (Khan)for a few days and then, the Turkish soldiers came back and took him. Ironically, this Palestinian Arab became the servant of the Ottoman State $^{9}$ and collected taxes from the people for the State.

From the hierarchal point of view, we can see that the Ottoman Caliph stands at the top of the pyramid, then the Walis (Governors) who are appointed by the Sultan, and then the Arabs who controlled one another. These Arabs are represented in the novel by the 'al-Habbab' who was feared by everyone. This person was given absolute authority by the Ottoman ruler and he was able to take a mother from her children after can kill her husband because he admired her, and he could lead her to his house in front of the whole people of the village and no one would dare to face him because the Qaimaqam promised him:

"Now we will complete our favor; you know that we choose a number of merchants, dignitaries and usurers whom we trust to enter an auction every year; the one who wins, will pay us the required taxes from the people of his area in advance and then we provide him with the necessary power to collect what he paid and what he should gain, of course. This season, we will not do that; I will leave you get what you can this year and next year, too. I am sure of that; you will have whatever you want, the power that you need and our protection; what we want from you is that you humiliate them, those who started daring to raise their voice and ask to separate and incite the people against the high State" 10 .

From this quotation from the novel, we see a great change that took place in the relationships between the Ottoman State and the Palestinian population. The reasons for this change were plenty. Sultan Abd al-Hamid II (1842-1918) was 34 years old when he assumed the throne in August $31^{\mathrm{st}}$, 1876, after toppling his brother Murad III. At that time, Bosnia and Hersek (Herzegovina) were making a revolution for their independence and then Serbia and Romania followed them and revolted.

In 1877, the Ottoman Empire was engaged in a new war against Russia. In the second year of his rule, the Sultan Abdul-Hamid II found himself "compelled to give up fifth of the properties of his empire and more than five and a half millions of the population, most of whom were Moslems 11 .

\footnotetext{
$\overline{9}$ Nassralla, Ibrahim (2007). Zaman al-Khoyoul al-Bayda', p. 12. ${ }_{11}^{10}$ Ibid. p. 27.

${ }^{11}$ Aoki, M. Kamel (1992). Al-Sultan Abd al-Hamid al-Thani bayn al-Sahyuniya al'Alamiya wal-Mushkila al-Falastiniya, p. 38-41.
} 
The cost of the wars that the Ottoman Empire entered in that period was very heavy on the level of casualties, wounded soldiers, equipment and expenses. The people of Palestine, too, had to bear a lot of the results of those wars and consequently, they started to suffer under the burden of the increasing heavy taxes on the one hand, and the escalation of recruitment of young men to the army, on the other. According to the British Consul in Syria, 115000 men were recruited from the Syrian provinces in 1877/1878". The British Consul in Jerusalem mentioned that 12000 persons from Jerusalem Muatasarrifate / Mutassarifiya / Province took part in the war and only a quarter of them returned in the summer of 1879 .

According to Yusuf al-Khaledi, "Palestine and al-Balqa' had more than 10000 casualties in the war". Since the middle class and the high class paid "participation fees", the burden of the war and recruitment fell on the shoulders of the poor people from the residents of the Moslem villages before others" ${ }^{12}$.

We see that these historical events are reflected in the text of the novel. For example, the government "doubled the number of the recruited young men whom it needed as soldiers; only few escaped the recruitment besides those who were able to pay sixty Ottoman liras as a participation fee to the Government, and that was not a small amount of money in those days. Besides, that payment did not exempt them from serving for five months at the nearest position to their villages and cities, but those who were not able to get away by paying money or by escape, found the trains waiting to transfer them to serve the military service at places they did not know.

The men who were married to foreign women who were not from their village or city were exempted from the military service. Other people who were exempted include: men who were married to minor wives who had no one to support them, Sharia judges, teachers who teach religious teachings, custodians of the shrines of messengers, pious men and sheikhs of Sufi ways, imams of mosques, orators, handicapped people of chronic diseases... and only children" ${ }^{13}$.

In this context, the narrator in the novel tells a tragic-comic story that happened to al-Barmaki. The story says that al-Barmaki's wife gave birth to a boy while he was absent and she called him Yunis, after her father's name. The midwife Shannara went to register him at the registration office. When the alBarmaki returned and knew that his son's name is Yunis, he was angry and asked the midwife Shannara to find a solution because he wanted people to call him "Abu Gazi". When his wife did not get pregnant again, the midwife found a solution. She went to the registration office after a year and admitted that the wife gave birth to another child who was named Gazi. The midwife

\footnotetext{
${ }^{12}$ Ibid., p. 38-41.

${ }^{13}$ Nassralla, Ibrahim (2007). Zaman al-Khoyoul al-Bayda', p. 141-142.
} 
got a birth certificate for him though the man had only one child. When the time of recruitment to the army came, the governmental officials found that al-Barmaki had two birth certificates, one for Yunis and one for Gazi, so they took his only son, Gazi, who he did not return! 14

\section{The Economic Situation}

Industry in Palestine remained characterized by its traditional handicrafts. Modern industries were started by German and Jewish settlers. Among the most important industries that were known in Palestine is the soap-industry, which was centered in Nablus. Besides, centers of souvenirs made of olive wood prospered there in addition to seashell industry, olivepresses and wheat-mills 15 .

However, the phenomenon that deepened in that period is the increase in the overflow of foreign products into the Palestinian markets. The increased connection of the Palestinian economy with the international economy, the changes that occurred in the social conditions and the rise in the cost of living (in the first period of the Ottoman rule) enhanced the people's interest in foreign products, which flooded the markets and competed with the traditional local products, which were not well protected by the customs system. "The customs duties were very slight; they started at 3\% and ended at $11 \%$ of the value of the imported goods" ${ }^{16}$. Therefore, we find that when Khaled, the hero of the novel, tells his mother that he wants to get married, he enters the kitchen and breaks a plate. His mother was pleased and ran and said: "the evil was broken", but he carried in his hand one of the Chinese flowered plates, which Haj Mahmoud had bought from a Turkish Daraki / soldier and broke it and the shreds spread on the floor... and to be true, Munira had been waiting impatiently to hear that one of the house plates was broken, but she was not ready to sacrifice the Chinese plates, no matter what the reason was. 17

The historical sources mention that the economy of Palestine remained, basically, agricultural till the end of the Ottoman era. Agriculture remained the main economic activity of the people and it depended on rainwater to a large extent and, consequently, it was affected by the increase or decrease of rainfall.

Agricultural kinds in Palestine remained nearly the same except for the major development that took place in citrus cultivation, which occupied the second degree in its significance after wheat on the list of the imported

\footnotetext{
${ }_{15}^{14}$ Ibid., p. 56 (In the scene of: the Curse of the Name).

${ }_{16}^{15}$ Rafiq, Abd al-Karim (1990) Falastin fi 'Ahd al-'Uthmaniyin (2), p. 954-958.

${ }^{16}$ Awad, Abdel Aziz Mohamed (1983). Muqadima fi Tarikh Falastin al-Hadith 18311914, p. 104-105.

Nassralla, Ibrahim (2007) Zaman al-Khoyoul al-Bayda', p. 13.
} 
products from Palestine in the eighties of the nineteenth century. Then, citrus export jumped to the first place in $1904^{18}$.

However, the products of this land, as they are mentioned in the novel of Zaman al-Khoyoul al-Bayda', did not go to the population or the farmers because tenth of the products were collected by the Monastery and the Priest, who was collecting that tenth for the State, as he said. For example, Father Theodorus was the man who introduced the oil-press to the village and put it in the backyard of the Monastery, and thus, he relieved the people of the village from the inconvenience of traveling to press their olives in other places. The historical sources mention that the agricultural yields constitute the most important exports of Palestine and their size was connected to the nature of the agricultural seasons. For example, the economic conditions in 1879 worsened as a result of shortage of water, weakness of the agricultural products and rise of prices, which led to paralysis of the commercial traffic ${ }^{19}$.

Palestine continued to export wheat to Europe. Two thirds of the wheat that was exported from Akka (Acre) was brought from Houran plains and the third third came from north of Palestine from the areas of Akka, Nazareth and Tiberias. Besides, the ports of Palestine, Jaffa, Haifa and Akka continued to export barley, maze, sesame, olive oil, soap an sheep wool ${ }^{20}$. Of course, the State had its quota of all this. The Priest Theodorus in the novel was careful to collect the (osher/ usher) of the gross yield and he had his excuses for that: "Don't forget, Haj, that what you give is a deposit that I have to give to the State, and I do not want to go to State with incomplete tithe ${ }^{21}$.

The novel mentions that a lot of villages that could not pay the tithe (usher) to the State and could not pay off the debt, were sold by the State to money owners who were able to pay taxes for them: "Haj Mahmoud knew that the existence of the Monastery was inevitable after the Turks sold tens of villages in auction to owners from Syria and Lebanon when these villages failed to pay the tithe (usher) for two consecutive years and their debts accumulated". $^{22}$ Here, it is necessary to point out that the religious people, especially the Christian ones from Greece, were appointed by the Ottoman State, and they constituted a branch of State authority. It was mentioned in the margin of the version that was given by Georgio, who came to work and worship at the Monastery at the village of al-Hadiya, that, historically, "the first Greek Patriarch who was appointed by al-Bab al-'Ali (Topkap1 Palace/ Sultan) to serve at the Jerusalem Church was Patriarch Jermanus, and thus, the appointment of Patriarchs in Jerusalem moved to the hands of the Ottoman

\footnotetext{
${ }^{18}$ Manna', Adel (2003). Tarikh Falastin fi Awakher al-'Ahd al-'Uthmani 1700-1918, p. 217-221.

${ }^{19}$ Ibid., p. 217-221.

${ }^{20}$ Schulz, Alexander (1988). Tahawulat Jazriya fi Falastin 1856-188, p. 96-98.

${ }_{21}^{21}$ Nassralla, Ibrahim (2007). Zaman al-Khoyoul al-Bayda', p. 59

${ }^{22}$ Ibid., p. 60.
} 
Sultans in Constantinople, who replaced the Greek Emperors, and Jermanus adopted a policy through which he intended to exclude the Arab elements from the administration of the Patriarchate and the high ranks of the church. The Arab elements started demanding their rights since the nineteenth century" $^{23}$, which compelled the people to declare revolution against the Church and declare their boycott to it ${ }^{24}$.

Again, it is worthwhile mentioning the role of the people who were appointed by the State to collect taxes including the Arab people from the same villages, who ruled the people under the protection of the State. These people intimidated the people and killed them if they refused to pay the 'usher' taxes. An illustration to that is the story of Habbab who murdered the man who dared to ask: "Which money do you want us to pay to you?" Habbab stabbed the man with his dagger and killed him. That was enough to make the villages that spread in that space submit" 25 .

Besides the religious people and the people whom the State employed to collect taxes, the State sent the Yawer to collect taxes and levies. The story says: "But everything started to sway when the Ottoman Empire started to sway, too, and it was ready to do anything in order to get money and the recruited men, and thus, the tax officer closed on the villages from all sides. The people found themselves forced to pay taxes not only on their own yields, but on their horses, sheep and other animals and even about every human head; the time soon came when people had to pay the tax of al-Shaniya for anyone who puts any cloth cover on his head such as a kaffiya, turban, and a fez" ${ }^{26}$.

The historical sources mention that the Ottoman State used to collect taxes/ levies on trees, which were called "kuraj/ land tax". It also collected tax on goats, called "rasm/ fee". The Ottoman authorities also collected fees on bee-hives as bee-keeping (apiculture) was common in Bilad al-Sham (Syria) in that period. The Ottoman State also collected taxes on exported or imported materials known by the name Iskala-Yield, namely "seaport taxes". Besides, the courts charged people specific taxes when they dealt with their issues and cases, or made wedding-contracts or registration of a document. Taxes on wedding-contracts were called 'Rasm Arous/ a Bride's Fee'. Part of these fees was given to the judge and those who worked with him at the court but the major share was given to the Za'amet (land tenure) or Timar (land granted by the Sultan).

When a crime or a robbery took place, the State would take fees from the responsible ones for their crimes, called "Crime Fees". However, if the criminals were unknown, the people of the neighborhood would be forced to

\footnotetext{
23 Ibid., footnote, p. 32.

${ }^{24}$ Ibid., p. 87, (Scene of al-Muqata'a).

25 Ibid., p. 45.

${ }^{26}$ Ibid., p. 46.
} 
pay those fees $^{27}$. The novel mentions that the main complication and the whole problem occurred because of the tax-collector, the Yawer and the soldiers who came to the village and confiscated the people's money and objects. "One evening, a group of Darak/ soldiers arrived at Hadiya village headed by a Yawer or a 'military assistant' with one of the tax collectors... who said to the people: the taxes that you pay are less than this trivial tithe (usher) that you hand to the Monastery. We observed this for a long time. The result was that what reaches the State does not include what you have of cows, sheep, cattle, horses, camels and human beings; we will not go out of this place till we count everything 28 .

Among the things that they took was the beautiful white mare that Khaled, the hero of the novel, fell in love with and continued to love after his bride-wife died. "They (the soldiers) slayed the livestock, chickens, pigeons, and anything that they did not need; then they roamed around the village several times and through its fields so that a lot of the sesame fields became useless.

In the afternoon of the third day, they decided on the amount of taxes that the people have to pay to them, and when they reached the point of determining the amount of taxes that the family of Haj Mahmoud has to pay, the tax collector said, without introductions: and on this white mare, there is a tax, too, and a tax on what is in her womb, too, and then he paused and said that sentence, which they feared: and this mare will be your gift to our Wali in return for the due taxes on this house" ${ }^{29}$.

This decision gave rise to all the following events in the play as Khaled could not give up his mare. It is his sweetheart and his honor. Khaled lurked to the Yawer and his assistant on their way and started killing the soldiers one by one till he finally killed the Yawer himself. The Ottoman authorities got mad and considered the event as a declaration of a revolution against them. They attacked the city, and the majority of its men left it, escaped and hid from the soldiers. The Bekbashi (lieutenant colonel) exploited the enmities between a lot of families as a strategy to know who the murderer was and "announced about a great prize of twenty-thousand piasters that would be given to anyone who would give information that would help to arrest the fugitive criminals" ${ }^{30}$.

\section{The Political Fluctuations}

After the year 1882, the interest of the Ottoman Government in Palestine increased for two reasons: on the one hand, it became a border region after Britain's occupation of Egypt, and on the other, it became a focus of

\footnotetext{
${ }^{27}$ Al-Bakhit, Muhammad Adnan (1979). Haifa fi al-'Ahd al-Uthmani al-Awwal, $\mathrm{p}_{8} 302-303$.

Nassralla, Ibrahim (2007). Zaman al-Khoyoul al-Bayda', p. 115. ${ }^{29}$ Ibid., p. 116.

${ }^{30}$ Ibid., p. 130.
} 
attention of the Zionist Movement that started to settle in the country. The relationships between the Ottoman Sultanate with Britain deteriorated after Britain's occupation of Egypt. Besides, its relationships with France witnessed retreat after France's occupation of Tunisia in 1881. In order to balance the relationships of his country with the European countries, Sultan Abd al-Hamid II "reinforced cooperation with the young Germany, and this reinforcement of the Ottoman-German relationships was reflected on Palestine since the last decade of the nineteenth century through the increase of German investments in Palestine and the rise of the status of the German consuls in the region" 31

The novel mentions that "the Turks became a dumb machine in the hands of the Germans who led them into military campaigns and their main interest was to engage the British, and we (the Arabs) cannot organize ourselves socially, as we do not trust one another; besides, we lack the idea of being engaged in public issues and if someone gets engaged in them, he will exploit them as a medium for his popularity and benefit" $"$.

The foreign political influences from Egypt, Britain and Germany and the Ottoman Empire occupation with their external wars led to worsening of the conditions of the greater State. The condition of Palestine and other states worsened and people lived in misery and suffering. The compulsory taxes exhausted the peasants and compelled them to abandon agriculture and cultivation. The lands dried, yields were scanty, and the young men were persecuted because they escaped from recruitment. Diseases and poverty increased in the countries, which was negatively reflected on their life. The large number of the wars of the State with the avaricious countries and forcing the young men to join the armies to fight outside their regions (a deed known by the name of Safar Barlek) created uncomfortable feelings among the citizens and dissatisfaction among the people with the behavior of the rulers and those who control the life of the people.

One of the men in the novel says: "if there was no persecution, Sheikh Nasser, we would not reach the weakness and degradation that we reached; you see how the treatment of the Turkish officers to the Arab soldiers is and how these soldiers started deserting the army; and the tendency of Arabism started to wake up at a time in which many dignitaries and leaders gave in to the demands of the Turks" 33

After the Constitutional Amendments in 1908, Jamal Pasha, the Butcher (1873 - 1922) ruled the Vilayet Damascus, Jerusalem and Palestine became under his authority. Jamal Pasha led the countries to a horrible state of unpreceded condition of injustice and persecution in Palestine. He applied a

\footnotetext{
${ }^{31}$ Manna', Adel (2003). Tarikh Falastin fi Awakher al-'Ahd al-'Uthmani 1700-1918, p. 216-217.

${ }_{33}^{32}$ Nassralla, Ibrahim (2007). Zaman al-Khoyoul al-Bayda', p. 136.

${ }^{33}$ Ibid.
} 
policy of Turkification in this period and the Arabs lost their positions. The high jobs were given to the Turks, and not any Turk, but those who were connected to The Committee of Union and Progress.

It is mentioned in the novel that "You can imagine the event of Jamal Pasha's hanging of the son of Fawzi al-Azem, where the latter did not show anything except his external approval; Jamal Pasha despised this nation that adores leaders who pretend untruly to be content with hanging their sons by the gallows" ${ }^{34}$.

\section{The Educational System}

According to various historical sources that the novel relies on, there was no system of education in Palestine in that period. Education was limited to the existence of few schools that were scattered in the whole of Palestine, and the level of education was very low. At the end of the nineteenth century, some European missionary schools appeared in different cities and villages. The novel mentions that Mahmoud Ibn Khaled finished his studies at alNajah Elementary School in Nablus. The writer mentions in the margin of that page a piece of information that is quoted from some sources saying: "The first attempt to establish this elementary school took place at the end of the Ottoman rule, but it was refused because of the political conditions that the Ottoman State was undergoing at the end of its rule to the Arab region.

\section{The Intellectual and National Trends}

In this period, the intellectual and national trends started to appear and the Ottoman authorities tried to limit the establishment of schools in order to curb and limit the national feelings that started to spread and rise ${ }^{35}$. The novel also mentions that when priest Elias al-Khouri started serving at the Monastery of al-Hadiya village, "he did not find newspapers or magazines as he did (in alQuds) where he was one of the readers of al-Assma'i and al-Quds newspapers. The mornings of Tuesdays and Fridays, the days in which al-Carmel newspaper was issued, became dry because he could not read the articles written by Najib Nassar. Najib Nassar, as it is mentioned in the margin of the play, was Sheikh of the Palestinian journalists, the owner of al-Carmel newspaper, which was published in Haifa in 1909, and Nassar was its chief editor and one of the most daring writers". 36

The religious characteristic dominated the educational life in Palestine, which was intertwined with the cultural life in Damascus and Cairo, where there were no borders that stand in the face of the religious scholars (u'lama) or geographic obstacles that oppose their movements.

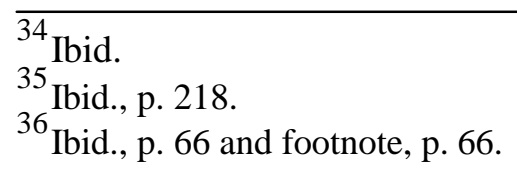


The sixteenth century had witnessed a peak of building religious buildings including mosques, hospices and schools, which were at that time representatives of the cultural activity in Palestine ${ }^{37}$. Rafiq maintains that in the absence of deep comprehensive studies of the cultural life in Palestine, the researcher will not be able to study "measurements of the fame of the religious scholars ('ulama') on the Islamic level or the local level," or determine the "role that they perform as notables among the scholars of the cities of popular leaders". He has no choice but to depend on the names of the scholars who are mentioned in the books of biography "to follow the people who enjoy scientific fame in Palestine" ${ }^{38}$

\section{Conclusion}

The novel of Zaman al-Khoyoul al-Baida'/ Time for White Horses by Ibrahim Nasralla is a historical novel that spans over a long period of time that covers three generations from 1880s to the establishment of the state of Israel in 1948. The events take place in one location - a small village in Palestine called 'Hadiya', which serves an allegorical function with respect to Palestine as a whole.

As we have seen, the study focuses on the three main dimensions that Palestine has undergone throughout that period with a special focus on the Ottoman period. The goal of the study was to find out the nature of the historical, administrative, economic, political, educational and cultural dimensions in the Palestinian life and how they are reflected in the contents of the novel.

After the novel was published and translated into English and Hebrew, a lot of readers wondered: how could we know the events and stories that are mentioned in the novel without this oral documentation? Generally, historical novels depend on history books and documented events, while this novel gains its significance from its documentation of historical events that are not mentioned in any written source, and it depends on the stories of the people who lived in those periods. In fact, this documentation is not biased according to the history writer and his goals, and it is biased only to the social life and the people who lived in those periods and know these stories. The reader and the researcher deduce the entity of the social and political life at that time by themselves, through the description of the narrator and without the writer's interference.

\footnotetext{
${ }_{37}^{37}$ Rafiq, Abd al-Karim (1990) Falastin fi 'Ahd al-'Uthmaniyin, vol.1, p. 830-831.

38 Ibid., p. 787-789.

${ }^{39}$ Matter, Karim (2014). Out of Time: colonial history in Ibrahim Nassralla's Time of White Horses. Journal of Postcolonial Writing, Vol. 50, N0. 2, 181.
} 
The study maintains that the writer most likely intended to emphasize the Palestinian special identity and its historical continuity through the stories that he collected from people who lived through the three periods of occupation of Palestine - the Ottoman, the British and the Israeli.

Finally, it is worthwhile mentioning that the study did not deal with the novel from the artistic point of view and left that for a detailed study that explores the form and contents of the novel as a historical novel and its interaction with other Palestinian or Arab novels in structure, setting, themes, plot, events, characters, style and message. 


\section{References:}

al-Bakhit, Muhammad Adnan (1979). Haifa fi al-'Ahd al-'Uthmani al-Awwal. Dirasa fi Ahwal Imran al-Sahel al-Shami, in: Second International Conference of the History of Bilad al-Sham in December 1979. University of Damascus. Faculty of Humanities, Part One, p. 299-322.

Aoki, M. Kamel (1992). Al-Sultan Abd al-Hamid al-Thani bayn al-Sahyuniya al-'Alamiya wal-Mushkila al-Falastiniya. Translated from English into Arabic by Ismael Sadiq. Al-Zahra' li al-'I'lam al-'Arabi.

Awad, Abdel Aziz Mohammad (1983). Muqadima fi Tarikh Falastin alHadith 1831-1914. Beirut: al-Mua'asasa al-'Arabiya li al-Dirasat wa alNashr. Awad, Abdul Aziz Mohammed (1969). Al-Idara al-'Uthmaniya fi Wilayat Sourya1864-1914, Cairo, Dar Al Ma'arif, Egypt.

al-Buraymi, Abdalla (2006). Ibrahim Nassrallah... al-Adab Tanqiya li alDhakera wa Ansana li al-Tarikh , in Mawsu'at Anhath wa Dirasat fi al-Adab al-Falastini al-Hadith. Part 4, p. 12.

Domani, Bishara (2009). Madkahl: Arshafat Falastin wa al-Falstiniyin: Irth Ihsan al-Nimer, in: Awraq 'Ai'liyafi al-Ijtima'I al-Mu'aser li Falastin. Edited by Zakariya Muhammad, Khaled Farraj, Salim Tamari, Issam Nassar. Jerusalem: Mu'asasat al-Dirasat al-Maqdisiya, p. 11-19.

Domany, Bishara (2002). I'adat Iktishaf Falastin. Ahali Jabal Nablus, (17001900), $2^{\text {nd }}$ edition. Beirut: Mu'asasat al-Dirasat al-Falastiniya.

Ghanayem, Zuhair Abdel Latif Mahmoud (1992). Wilayat Beirut fi Fatrat alTanzimat: Dirasa fi al-Awda' al-Idariya wa al-Iqtisadiya wa al-Thaqafiya, in: al-Bakhit, Muhammad Adnan , Marzouq, Muhammad Yunis (eds.), Buhuth fi Tarikh al-Sham fi al-Assr al-'Uthmani. Manshurat Lajnat Tarikh Bilad alSham. University of Jordan, Yarmouk University, Amman, pp. 132-193.

Ghanayim, A. Zuher (2005). Liwa'Akka fi 'Ahd al-Tanzimat al-'Uthmaniya 1281-1337 h./ 1864-1918 AD, $2^{\text {nd }}$ edition. Beirut: Mu'asast al-Dirasat alFalastiniya.

Hirschhorn, Norbert (2012) Time of White Horses. In: Banipal: Magazine of Modern Arabic Literature. On:www.banipal.co.uk/book_reviews/96/time-ofwhite-horses.

Hollander, Benjamin (January 24, 2013). A Palestinian Odyssey. Warscapes. On:www.warscapes.com/reviews/palestinianodysseyhttps://www.newstatesm an.com/culture/culture/2012/12/review-time-white-horses.

Hussein, Tam (December $\left.4^{\text {th }}, 2012\right)$. Time of the White Horses. In: The New Statesman. On:

https://www.newstatesman.com/culture/culture/2012/12/review-time-whitehorses.

al-Jayyusi, Salma al-Khadra (2009). Tba'ah Khassah min al-Malha alFalastiniya li Ibrahim Nassralla. In Jaridat al-Ghd: A Reserved Copy on May, $26^{\text {th }}, 2009$. 
Khalaf, Tayseer (2010).Wasf Falastin Awakher Ayyam al-'Uthmaniyin 18981916: Rihlat wa Mudhakarat. Damascus: Dar Kin'an li al-Dirasar wa al-Nashr. Manna', Adel (2003). Tarikh Falastin fi Awakher al-'Ahd al-'Uthmani 17001918, (a New Reading) $2^{\text {nd }}$ edition. Beirut: Mu'asasat al-Dirasat al-Falastiniya. Manna', Adel (2008). Liwa al-Quds fi Awaset al-'Ahd al-'Uthmani: al-Idara wa al-Mujtama' Munzu Awaset al-Qarn al-Thamin Ashar hatta Hamlat Muhammad Ali Pasha 1831. Beirut: Mu'asasat al-Dirasat al-Falastiniya.

Matter, Karim (2014). Out of Time: colonial history in Ibrahim Nassralla's Time of White Horses. Journal of Postcolonial Writing, Vol. 50, N0. 2, 176188. Routlege: Taylor and Francis Group.

Nassralla, Ibrahim (2007). Zaman al-Khoyoul al-Bayda'. Beirut: Al-Dar al'Arabiya li al-U'lum Nashirun.

Nassralla, Ibrahim (2012). Time of White Horses. Translated by Nancy Roberts. Published by The American University Press in Cairo.

Qasmiyeh, Khayriyeh (1994). Al-Haya al-Fikriya fi Falastin Awakher al'Ahd al-Uthmani. Beirut: al-Ruwad li al-Nashr wa al-Tawzi'.

Qualey, Mrcia Lynx (2012). One-minute Review: Ibrahim Nasrallah's 'Time of White Horses' on: https://arablit.org/2012/.../one-minute-review-ibrahimnasrallahs-time-of-white-horses.

Rafiq, Abd al-Karim (1990) Falastin fi 'Ahd al-'Uthmaniyin (1): Min Matla' al-Qarn al-'Asher al-Hijri/ al-Sades Ahar al-Miladi ila Matla' al-Qarn alThalith 'Ashar al-Hijri/ al-Tasi' Ashar al-Miladi [1516-1800], in: al-Mawsu'a al-Falastiniyeh, al-Qism al-Thani, (al-Dirasat al-Khassa), al-Mujallad alThani, Beirut, p. 695-848.

Rafiq, Abd al-Karim (1990) Falastin fi 'Ahd al-'Uthmaniyin (2): Min Matla' al-Qarn al-Thalith 'Asher al-Hijri/ al-Tadi' Ahar al-Miladi ila al-'Am 1326 Hijri/ 1918 Miladi, in: al-Mawsu'a al-Falastiniyeh, al-Qism al-Thani, (alDirasat al-Khassa), al-Mujallad al-Thani, Beirut, p. 849-990.

Raya - Agency for Arabic Literature (January 27, 2013). A review of Ibrahim Nasrallah's Time of White Horses. On: www.rayaagency.org/2013/01/a-reviewof-ibrahim-nasrallah-s-time-of-white-horses.

Saleh, Fakhri (2020). Saleh, Fakhri (2020). "Al-Nakba wa al-Riwaya". At: al-Arab Website: https://alarab.co.uk. retrieved on 09/02/2020.

Schulz, Alexander (1988). Tahawulat Jazriya fi Falastin 1856-1882: Dirasat Hawl al-Tatawur al-Iqtisadi wa al-Ijtima'i-al-Siyasi. Translated from German by Jamil al-'Asali. Amman: Manshurat al-Jami'a al-'Urdoniya.

Schulz, Alexander (1992). Al-Quds fi al-Qarn al-Tasi' A'sher 1831-1917. In: al-Quds fi al-Tarikh. Translated from German by Jamil al-Asali. Amman: Manshurat al-Jami'a al-'Urdoniya, pp. 273-303.

Srour, Mousa (2009). Sijilat Mahkamat al-Quds al-Shar'iya: Ishkaliyat Manhajiya, in: Awraq 'Ai'liyafi al-Ijtima'I al-Mu'aser li Falastin. Edited by Zakariya Muhammad, Khaled Farraj, Salim Tamari, Issam Nassar. Jerusalem: Mu'asasat al-Dirasat al-Maqdisiyeh, p. 23-36. 
Sudiro Suryo, M. Hum (2020). The Depiction of Native American in the Novels of Forrest Carter, International Journal of Linguistics, Literature and Culture, March, vol. 7, N0. 1., p. 15; for full description of the theory, see: Hamilton, Paul (1996). Historicism. New York: Routledge. 